\title{
Irrational Discourse as a Form of Violation of the Other with Words ${ }^{\dagger}$
}

\author{
Francesca Vidal \\ University Koblenz-Landau, Thomas Nast Str. 44, 76829 Landau, Germany; vidal@uni-koblenz-landau.de \\ + Presented at the IS4SI 2017 Summit DIGITALISATION FOR A SUSTAINABLE SOCIETY, Gothenburg, \\ Sweden, 12-16 June 2017.
}

Published: 8 June 2017

Keywords: irrational discourse; hate speech; echo room facebook; rhetoric

At re: publica 2010 Sascha Lobo gave a lecture entitled 'How to Survive a Shitstorm'. Thus he established the term. The term 'Shitstorm' describe a phenomenon often observed on the social web: One or two critical remarks trigger aggressive, insultung and even threatening verbal attacks which culminate in a 'wave of indignation' through active as well as seemingly passive actors.

The platforms of the social web have a communication potential creating an online community which can always go beyond the circle of addressees. Thus, a viewer or a reader can become an actor at any time, and the discourse can spread across other platforms. The menbers may transfer the discourse onto other platforms thus turning themselves from passive recipients into active participants. What is noticeable here is that private issues becomes public, the public issues becomes private. In recourse to Hannah Arendt, we can therefore speak of a dwindling public sphere.

Only when one is concerned with the performative character of the language, however, can one explain why words can hurt and why these injuries are the expression of a failure to acknowledge and respect the other. It is also possible to discuss whether irrational discourses are not injurious per se, as exemplified by the debate on the so-called 'Lügenpresse', the lying press-a term which was coined during the 19th century in Germany and has been revised in recent years by right-wing nationalist and xenophobic movements and organisations.

Finally, the question arises about the possibilities of resistance. A model for this is provided by Judith Butler's concept of resignification as a possibility of verbal resistance.

Conflicts of Interest: The authors declare no conflict of interest.

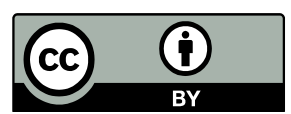

(C) 2017 by the authors. Licensee MDPI, Basel, Switzerland. This article is an open access article distributed under the terms and conditions of the Creative Commons Attribution (CC BY) license (http://creativecommons.org/licenses/by/4.0/). 